\title{
Competitive Advantage and Corporate Governance in Indonesia with Enterprise Risk Management as Mediating
}

\author{
Samuel $^{*} \quad$ Yvonne Augustine \\ Trisakti University - Faculty Economic and Business Kyai Tapa No.1 Tomang, Grogol petamburan, West \\ Jakarta, Jakarta 11440
}

\begin{abstract}
The objective of this research is the implementation of Good Corporate Governance in Indonesia began to be intensified by the government since the events of the Indonesian economic crisis in 1997-1998. Because, at that time almost all of the companies in Indonesia still used traditional governance, where company owners became company managers. Because of that, suspected because there is no separation between the supervision and management system resulting in many conflicts of interest in companies in Indonesia, it is one of the factors that exacerbate the economic crisis. At present in the industrial revolution 4.0 that will be faced, the implementation of Good Corporate Governance is expected to be the key determinant in maintaining the level of stakeholders' trust in corporate governance.In this article, the author will try to analyze the implementation of Good Corporate Governance in companies with Competitive Advantage and the influence of Enterprise Risk Management in mediating the relationship between the three variables.
\end{abstract}

Keywords: Enterprise Risk Management, Good Corporate Governance, Cost Leadership Strategy, Diffetentiation Strategy, Indonesia

DOI: $10.7176 / \mathrm{JESD} / 10-8-05$

Publication date: April $30^{\text {th }} 2019$

\section{Introduction}

In a highly dynamic business environment such as today and increasingly competitive, companies are required to be able to increase their competitive advantage to be able to compete in the market besides the greater the risk in the market, both strategic risk, financial risk, competition risk, operational risk, and reputation risk. However, the level and method of implementing Enterprise Risk Management will vary in each company due to various things, one of which is due to the business strategy chosen by the company.

Therefore, companies must be able to manage risks that are likely to be faced, starting from the ability to analyze risks to the stage of implementing actions to minimize these risks and evaluate the implementation that is tailored to the needs of the company. And this must be supported by Corporate Governance that can support the company's ability to implement Enterprise Risk Management to be able to create business sustainability and maximize company capability to be able to compete or win the market for their business.

\section{Literature Review}

\subsection{Enterprise Risk Management}

A risk is a condition that occurs due to uncertainty. In the business world something uncertain is very vulnerable to occur, so the company will think about how to manage risk well in order to have benefits in the future. Hery (2015) in his book explains that Enterprise Risk Management is a systematic and sustainable process that is designed and run by management to provide adequate confidence that all risks that have the potential to have a negative impact have been managed in such a way that the company is willing to take the risk level.

The definition of Enterprise Risk Management according to COSO (2004) is as a process that is influenced by company management, which is implemented in every corporate strategy and is designed to provide adequate confidence in achieving company goals. The application of risk management also aims to identify the company's risk in each activity and measure and overcome it at a certain level of tolerance. The rationale for corporate risk management is that each entity exists to provide value to its stakeholders. All entities face uncertainty, and the challenge for management is to determine how much uncertainty to accept because it seeks to foster stakeholder value. Uncertainty presents risks and opportunities, with the potential to erode or increase value. Corporate risk management allows management to effectively deal with uncertainties and risks and related opportunities, increase capacity to build value.

Values are maximized when management establishes strategies and objectives to achieve the optimal balance between growth and profit targets and related risks, and efficiently and effectively uses resources to achieve the entity's goals. Corporate risk management includes:

1. Aligning risk appetite and strategy

Management considers the entity's risk appetite in evaluating strategic alternatives, setting related objectives, and developing mechanisms to manage related risks.

2. Enhancing risk response decisions 
Enterprise risk management provides precision to identify and choose among alternative risk responses - risk aversion, reduction, division and acceptance.

3. Reducing operational surprises and losses

Entities obtain enhanced capabilities to identify potential events and establish responses, reduce associated surprises and costs or losses.

4. Identifying and managing multiple and cross-enterprise risks

Every company faces a variety of risks that affect various parts of the organization, and company risk management facilitates effective responses to interrelated impacts and integrated responses to various risks.

5. Seizing opportunities

By considering various potential events, management is positioned to identify and proactively realize opportunities.

6. Improving deployment of capital

Obtaining strong risk information allows management to effectively assess overall capital requirements and increase the capital allocation.

\subsection{Good Corporate Governance}

The concept of comprehensive Corporate Governance began to develop after the events of The New York Stock Exchange Crash on October 19, 1987, where quite a number of multinational companies listed on the New York Stock Exchange suffered substantial financial losses. Anticipating the company's internal problems, executives conduct financial engineering which is essentially how to "hide" company losses or beautify the appearance of management and financial statements. Handling is done not only window dressing but also financial engineering. Normally in situations of conducive business conditions, there are no deviations in behavior by individuals or collectively in the company, but in times of difficulties, then all kinds of sources of irregularities (irregularities) and causes of loss and collapse of the company, starting from profiteering behavior, commercial crime to economic crime. High awareness to improve the nation's competitiveness by all statesmen, scholars, and businessmen, the movement began to improve good practices in the company. The movement began with figures in Britain led by Sir Ardian Cadburt, who at that time was Director of the Bank of England and former CEO of the Cadbury Group. Since the publication of Cadbury Code on Corporate Governance in 1992, more and more institutions have continued to refine the principles and technical guidelines of good corporate governance practices, including ICGN (International Corporate Governance Network) which encourages the Organization for Economic Cooperation Development (OECD) to issue OECD Principles on Corporate Governance. ICGN is very interested in GCG implementation because their members consist of pension funds and insurance institutions that manage customer funds for long-term investments. (Muchtar, 2002: 1).

Good Corporate Governance (GCG) is a healthy corporate governance procedure that has been introduced by the Indonesian government and the International Monetary Fund (IMF). This concept is expected to protect shareholders and creditors to be able to recover their investment. Indonesia began implementing the GCG principles since it signed a Letter of intent (LOI) with the IMF, one of the important parts of which was the inclusion of a schedule for improving the management of companies in Indonesia. In line with this, the National Committee on Corporate Governance (KNKCG) believes that companies in Indonesia have responsibilities that implement GCG standards that have been applied to international standards (Sutedi, 2011: 3). According to the Forum for Corporate Governance in Indonesia / FCGI (2001) defines Corporate Governance as "A set of rules that establish relationships between stakeholders, creditors, governments, employees and other internal and external stakeholders in relation to their rights and obligations, or in other words a system that directs and controls the company."

Decree of the Minister of BUMN No: Kkep-117M / MBU / 2002 Article 1 concerning the practice of Good Corporate Governance in State-Owned Enterprises (SOEs), it can be concluded that Good Corporate Governance is a system that regulates, manages and oversees business control for the success of the company's business as a form of attention to stakeholders and regulating the relationships and responsibilities between employees, creditors and internal and external stakeholders in controlling the company for the achievement of corporate goals to be achieved by interested parties and paying attention to the interests of stakeholders in accordance with the rules and regulations. invite.

In principle, corporate governance concerns the interests of shareholders, the role of all stakeholders in corporate governance. The principles of GCG compiled by the National Committee on Governance Policy (KNKG) (2006) include:

a) Transparency

Companies are required to provide sufficient, accurate, timely information to all stakeholders. Information disclosed includes financial conditions, financial performance, ownership, and management of the company. Openness is done so that shareholders and other people know the 
condition of the company so that shareholder value can be increased.

b) Indenpency

The company is managed professionally without conflicts of interest and influence/pressure from the parties or those that do not comply with the prevailing laws and regulations and sound corporate principles.

c) Accountability

Companies must be able to account for their performance transparently and fairly. For this reason, the company must be managed correctly, measurably and in accordance with the interests of the company while taking into account the interests of shareholders and other stakeholders.

d) Responsibility

Managers must provide accountability for all actions in managing the company to stakeholders as a form of trust given to them.

e) Fairness

The company must always pay attention to the interests of shareholders, other stakeholders and all people involved in it based on the principles of equality and fairness of stakeholders.

\subsection{Competitive Adventage}

The era of globalization has had an impact on the increasingly widespread competition in the global market and also as an example of demand theory. This, of course, caused intense competition for market players in the economic sector. In this case, of course, more sales value is needed so that of course it can capture the attention of the international market. In this case, Porter insisted that one way to win the competition is to have a competitive advantage. This opinion is further reinforced by the opinion of Day \& Wensley (1988), sustainable competitive advantage is one form of strategy for economic actors to maintain their survival.

This theory was coined by Michael Porter in a book entitled Competitive Advantage (1985). This theory emerged as a form of criticism of Ricardo's theory of comparative advantage. Competitive advantage is the heart of company performance in a competitive market. Competitive advantage is about how a company really puts generic strategies into practice.

Michael E. Porter describes the five strengths of a business strategy that is very decisive and becomes a market attraction. The five strategies will be discussed in the points below:

1. A threat of new entrants (threat of new entrants)

2. Supplier Bargaining Power (bargaining power of suppliers)

3. A threat of substitute products

4. The Power of Bargaining Bidding (bargaining power of buyers)

5. Competitive Competition among Industry Members (rivalry among competitive firms)

\subsection{Previous Research}

Elena Demidenko and Patrick McNutt (2010) in their research The ethics of enterprise risk management as a key component of corporate governance conducted in Russia and Ukraine found that ways for many organizations to improve their risk management practices are key components of applied ethics from governance. company management. Enterprise risk management is developed into philosophy to help organizations with the process of protecting shareholder value while also increasing profitability. Effective Enterprise Risk Management is based on the ethics of risk governance. Internal audits need to be involved in the process of integrating risk management and compliance. It must maintain a level of independence when assisted by forming or building Enterprise risk management. And the CRO will be more effective when positioned to be responsible for giving reports to the Board. In other words, this research concludes that risk management is the key to determining the formation of good corporate governance.

Furthermore, Akram Jalal-Karim with Leveraging enterprise risk management (ERM) research for Bahrain's competitive advantages in 2013 found that there was a very significant relationship between all factors identified from independent enterprise risk management variables in enhancing competitive business excellence. It also shows that, overall, the model applied is good enough in predicting successful readiness for each potential risk.

Sara Soltanizadeh, Siti Zaleha Abdul Rasid, Nargess Mottaghi Golshan, and Wan Khairuzzaman Wan Ismail (2016) Business strategy, enterprise risk management, and organizational performance found that companies with cost leadership business strategies were more motivated to implement ERM compared to companies with differentiation strategies. The results also show that ERM implementation has a significant positive impact on organizational performance. Although ERM is a partial mediator of the relationship between cost leadership strategies and organizational performance, ERM does not mediate the relationship between differentiation strategies and organizational performance. 


\section{Research Design}

The earliest step in the research is the identification of problems that are intended to reinforce the boundaries of the problem so that the scope of the research does not go out of its objectives. Followed by deciphering the background to deliver and explain the background of problems and phenomena in the field. If the background of the problem has been carefully described, then the subject matter to be examined is formulated in the form of question sentences and the answers to the research are sought.

In the form of inferential research, the writer must formulate the hypothesis of his research funding research framework (Picture 1), and determine the research variables then do the operationalization of each variable used which is presented in Table 1. The next step is to choose the research instrument. Measuring instrument variables play an important role in an effort to obtain accurate and reliable information. Even the validity of the results of the study largely depends largely on the quality of the data collection instruments.

The next step is determining the sampling method used in research and collecting research data from the field. The research data was collected both through data collection instruments, observations and through documentation data. After the data is obtained, data collection and analysis is carried out.

Table1. Operational Definition

\begin{tabular}{|c|c|c|}
\hline Variable & Definition & Indicator \\
\hline $\begin{array}{l}\text { Good } \\
\text { Corporate } \\
\text { Governance }\end{array}$ & $\begin{array}{l}\text { Good Corporate Governance is a system that } \\
\text { regulates, manages, and supervises business } \\
\text { control for the success of the company's } \\
\text { business as a form of attention to stakeholders } \\
\text { and regulates relationships and } \\
\text { responsibilities between employees, creditors } \\
\text { and internal and external stakeholders in } \\
\text { controlling the company to achieve the } \\
\text { company's goals. achieved by interested } \\
\text { parties and taking into account the interests of } \\
\text { stakeholders in accordance with the rules and } \\
\text { regulations. }\end{array}$ & $\begin{array}{l}\text { 1. Size of the Board of Commissioners } \\
\text { 2.Independent Board of Commissioners } \\
\text { 3. Institutional Ownership } \\
\text { 4. Managerial Ownership } \\
\text { 5. Audit Committee }\end{array}$ \\
\hline $\begin{array}{l}\text { Competitive } \\
\text { Advantage }\end{array}$ & $\begin{array}{l}\text { Competitive advantage is the heart of } \\
\text { company performance in a competitive } \\
\text { market. Competitive advantage is about how } \\
\text { a company really puts generic strategies into } \\
\text { practice. }\end{array}$ & $\begin{array}{l}\text { Michael E. Porter describes the five } \\
\text { strengths of a business strategy that is very } \\
\text { decisive and becomes a market attraction. } \\
\text { The five strategies will be discussed in the } \\
\text { points below: } \\
\text { 1. A threat of new entrants (threat of new } \\
\text { entrants) } \\
\text { 2. Supplier Bargaining Power (bargaining } \\
\text { power of suppliers) } \\
\text { 3. A threat of substitute products } \\
\text { 4. The Power of Bargaining Bidding } \\
\text { (bargaining power of buyers) } \\
\text { 5. Competitive Competition among } \\
\text { Industry Members (rivalry among } \\
\text { competitive firms) }\end{array}$ \\
\hline $\begin{array}{l}\text { Enteprise Risk } \\
\text { Management }\end{array}$ & $\begin{array}{l}\text { Enterprise Risk Management is a } \\
\text { comprehensive, integrated framework for } \\
\text { managing credit risk, market risk, economic } \\
\text { capital, risk transfer, to maximize corporate } \\
\text { value (Lam, James) }\end{array}$ & $\begin{array}{l}\text { 1. Strong leadership and commitment } \\
\text { from top management } \\
\text { 2. There are benefits obtained when } \\
\text { implementing risk management } \\
\text { 3. Regulations that require } \\
\text { implementing risk management } \\
\text { 4. There is adequate system support } \\
\text { 5. Adequate/sufficient budget }\end{array}$ \\
\hline
\end{tabular}

Variable measurements that will be used in this study are 1-7 Likert scale. Where data collection will be done by distributing questionnaires to respondents. In this study, the data collection method used was Questionnaire or Questionnaire. Questionnaire or questionnaire is a technique of collecting data through a form that contains questions that are submitted in writing to someone or a group of people to get answers or responses and information needed by researchers (Mardalis: 2008: 66) This study uses questionnaires or questionnaires, lists the questions made structurally with the form of multiple choice questions and open questions. This method is used to obtain data about the process of implementing enterprise risk management, good corporate governance, and competitive advantage. The population of this study is companies that operate and operate in the Jakarta area in particular. 
Picture 1. Research Framework

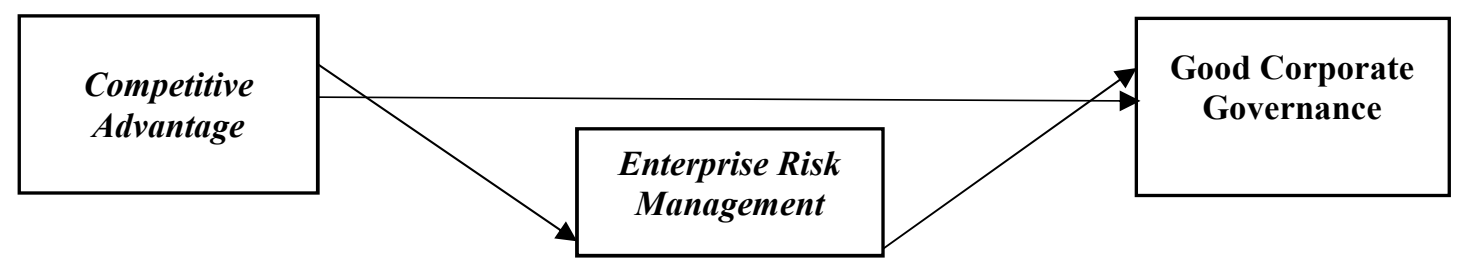

Following is the hypothesis that will be used:

H1: Competitive Advantage affects the implementation of Good Corporate Governance.

H2: Competitive Advantage affects the implementation of Enterprise Risk Management.

H3: Enterprise Risk Management has a direct effect on the implementation of Good Corporate Governance. H4: Competitive Advantage affects the Implementation of Good Corporate Governance by mediating by Enterprise Risk Management.

\section{Empirical Result}

\section{Reliability \& Validity Test}

The test criteria were carried out using Cronbach Alpha testing. This test is done with the aim to test the consistency of answers from respondents, which means if the respondent is treated repeatedly, the answers from the respondents will not change in the extreme.

A test can be said to have high validity if the test performs its measuring function, or gives accurate and accurate measurement results in accordance with the purpose of the test. A test produces data that is not relevant to the purpose of holding a measurement said to be a test that has low validity.

The other side of the notion of validity is the meticulous aspect of measurement. A valid measuring instrument can run its measuring function appropriately, also has high accuracy. The meaning of accuracy here is to be able to detect small differences that exist in the attributes they measure. The following is the result of testing the validity of the data used in this study.

a. Reliability \& Validity Test Good Corporate Governance

Table 2. Relianbility statistics of Good Corporate Governance

Reliability Statistics

\begin{tabular}{|r|r|}
\hline Cronbach's Alpha & N of Items \\
\hline .755 & 5 \\
\hline
\end{tabular}

KMO and Bartlett's Test

Kaiser-Meyer-Olkin Measure of Sampling Adequacy.

Bartlett's Test of Sphericity Approx. Chi-Square

df

Sig.

.774

72.027

10

.000

Judging from the results of Cronbach's Alpha in Table 2 obtained 0.755 (with criteria $>0.6$ ), it can be concluded that the 5 indicators used to measure the Good Corporate Governance variable are reliable. From the KMO results in Table 3 obtained 0.774 (with criteria $>0.5$ ), it can be concluded that the data used in measuring the Good Corporate Governance variable is valid.

b. Reliability \& Validity Test Enterprise Risk Management

Table 4. Reliability statistics of Enterprise Risk Management

\section{Reliability Statistics}

\begin{tabular}{|l|l|l|}
\hline Cronbach's Alpha & $\mathrm{N}$ of Items \\
\hline
\end{tabular}

$.914 \quad 11$

Table 5. Validity statistics of Enterprise Risk Management

KMO and Bartlett's Test

Kaiser-Meyer-Olkin Measure of Sampling Adequacy.

Bartlett's Test of Sphericity Approx. Chi-Square

df

Sig. 
Judging from the results of Cronbach's Alpha in Table 4 obtained by 0.914 (with criteria> 0.6), it can be concluded that of the 11 indicators used in measuring the Enterprise Risk Management variable, it meets reliability testing. Judging from the KMO results obtained by 0.871 (with criteria $>0.5$ ), it can be concluded that the data used in measuring Enterprise Risk Management variables are valid.

c. Reliability \& Validity Test Competitive Adventage

Judging from the results of Cronbach's Alpha Alpha in Table 6 obtained by 0.899 (with criteria> 0.6 ), it can be concluded that the 15 indicators used in measuring the competitive variable have met the reliability aspects. Judging from the KMO results obtained at 0.801 in Table 7 (with criteria $>0.5$ ), it can be concluded that the data used to measure Competitive Advantage variables can be said to be valid.

Table 6. Reliability statistics of Competitive Advanetage

Reliability Statistics

\begin{tabular}{|r|r|}
\hline Cronbach's Alpha & $\mathrm{N}$ of Items \\
\hline .899 & 15 \\
\hline
\end{tabular}

Table 7. Validity statistics of Enterprise Risk Management

KMO and Bartlett's Test

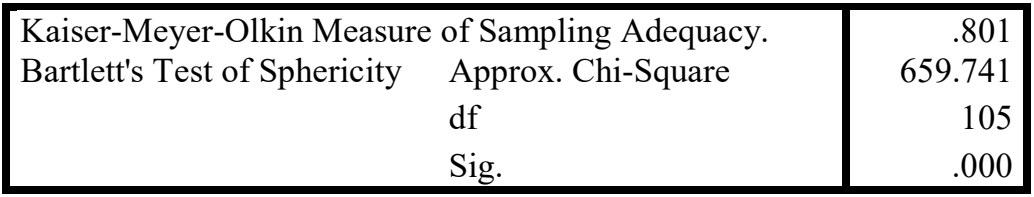

\section{Normality test}

Normality test is useful for determining data that has been collected normally distributed or taken from a normal population. The classic method in testing the normality of a data is not so complicated. Based on the empirical experience of some statisticians, data with more than 30 digits $(n>30)$ can already be assumed to be normally distributed. Usually said as a large sample. The following are the results of normality testing of the data used in this study. In Table 8 the results of the sig KS-Z obtained are 0.136 (with criteria $>0.05$ ), it can be concluded that the data used in this study is normal.

Table 8. Validity statistics of Enterprise Risk Management

\section{One-Sample Kolmogorov-Smirnov Test}

\begin{tabular}{|c|c|c|}
\hline & & $\begin{array}{c}\text { Unstandardized } \\
\text { Residual }\end{array}$ \\
\hline $\mathrm{N}$ & & 57 \\
\hline \multirow[t]{2}{*}{ Normal Parameters ${ }^{\mathrm{a}, \mathrm{b}}$} & Mean & .0000000 \\
\hline & Std. Deviation & 11.49857348 \\
\hline \multirow[t]{3}{*}{ Most Extreme Differences } & Absolute & .136 \\
\hline & Positive & .075 \\
\hline & Negative & -.136 \\
\hline Test Statistic & & .136 \\
\hline Asymp. Sig. (2-tailed) & & $.010^{c}$ \\
\hline
\end{tabular}

\section{a. Test distribution is Normal. \\ b. Calculated from data. \\ c. Lilliefors Significance Correction.}

\section{Test of Research Model}

In this study, we tested each hypothesis by analyzing the model in stages to see the effect of each independent variable on the dependent variable. The following are the results of model testing carried out using SPSS version 22 analysis software. The criteria for evaluating the results of this framework model test will refer to and see the Adjusted R Square and Sig values obtained.

\section{a. Testing the relationship of Competitive Advantage to Good Corporate Governance}

From the results of the analysis of the Competitive Advantage significance value of $0,000<0,05$ (Table 
9). So that directly there is a significant influence of competitive advantage on good corporate governance. Judging from the Adjusted R Square value of 0.365 (Table 8) this means that Competitive Advantage directly has a positive effect of 0.365 on the implementation of Good Corporate Governance.

(Ho1 Received).

Table 8. Testing the relationship of Competitive Advantage to Good Corporate Governance Model Summary ${ }^{b}$

\begin{tabular}{|l|r|r|r|r|}
\hline Model & $\mathrm{R}$ & R Square & Adjusted R Square & \multicolumn{2}{c|}{$\begin{array}{c}\text { Std. Error of the } \\
\text { Estimate }\end{array}$} \\
\hline 1 & $.614^{\mathrm{a}}$ & .376 & .365 & 4.72925 \\
\hline
\end{tabular}

a. Predictors: (Constant), $\mathrm{X}$

b. Dependent Variable: Y

Table 9. Testing the significance of the influence of Competitive Advantage on Good Corporate Governance

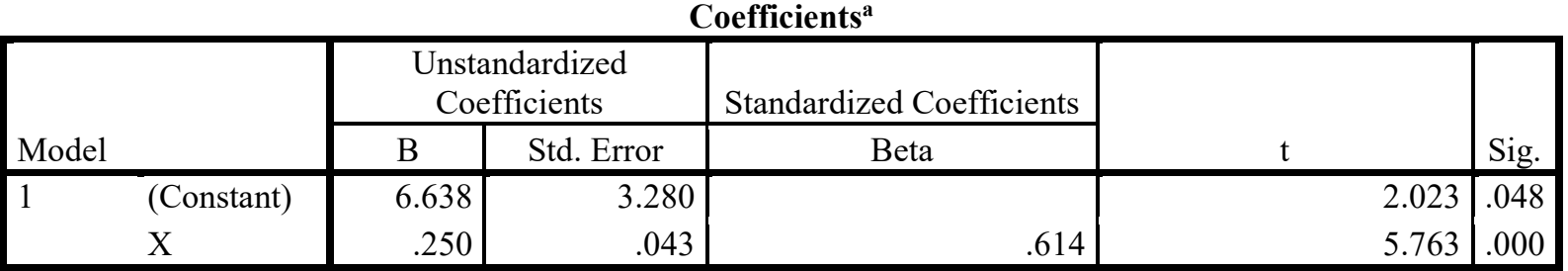

a. Dependent Variable: $\mathrm{Y}$

b. Testing the relationship of Competitive Advantage to Enterprise Risk Management

Table 10. Testing the effect of Competitive Advantage on Enterprise Risk Management Model Summary ${ }^{b}$

\begin{tabular}{|l|r|r|r|c|}
\hline Model & R & R Square & $\begin{array}{c}\text { Adjusted R } \\
\text { Square }\end{array}$ & $\begin{array}{c}\text { Std. Error of the } \\
\text { Estimate }\end{array}$ \\
\hline 1 & $.651^{\mathrm{a}}$ & .424 & .414 & 9.08443 \\
\hline
\end{tabular}

a. Predictors: (Constant), X

b. Dependent Variable: $\mathrm{Z}$

Table 11. Testing the significance of the influence of Competitive Advantage on the Enterprise Risk Management

\begin{tabular}{|c|c|c|c|c|c|c|}
\hline \multirow{3}{*}{\multicolumn{2}{|c|}{ Model }} & & Coetificients & & & \\
\hline & & \multicolumn{2}{|c|}{$\begin{array}{l}\text { Unstandardized } \\
\text { Coefficients }\end{array}$} & $\begin{array}{c}\text { Standardized } \\
\text { Coefficients }\end{array}$ & \multirow[b]{2}{*}{$\mathrm{t}$} & \multirow[b]{2}{*}{ Sig. } \\
\hline & & B & Std. Error & Beta & & \\
\hline & (Constant) & 15.770 & 6.301 & & 2.503 & .015 \\
\hline & $\mathrm{X}$ & .531 & .083 & .651 & 6.365 & .000 \\
\hline
\end{tabular}

a. Dependent Variable: $Z$

From the results of the analysis above the significance value of Competitive Advantage (Table 11) is $0,000<0,05$. So that directly there is a significant influence of competitive advantage on enterprise risk management. Competitive Advantage (Table 10) directly has a positive effect of 0.414 on Enterprise Risk Management. (Ho2 Received)

c. Testing the relationship of Enterprise Risk Management to Good Corporate Governance

Table 12. Testing the effect of Enterprise Risk Management on Good Corporate Governance

Model Summary ${ }^{b}$

\begin{tabular}{|l|c|r|r|r|}
\hline Model & $\mathrm{R}$ & $\mathrm{R}$ Square & Adjusted R Square & Std. Error of the Estimate \\
\hline 1 & $.765^{\mathrm{a}}$ & .585 & .578 & 3.85794 \\
\hline
\end{tabular}

a. Predictors: (Constant), Z

b. Dependent Variable: Y

Table 13. Testing the significance of the effect of Enterprise Risk Management on Good Corporate Governance 


\section{Coefficients $^{\mathrm{a}}$}

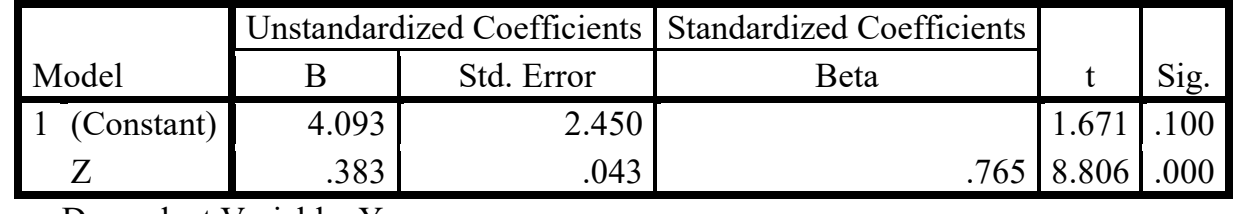

a. Dependent Variable: Y

From the results of the analysis above, the Enterprise Risk Management significance value (Table 13 ) is $0,000<0,05$. So that directly there is a significant effect of Enterprise Risk Management on Good Corporate Governance. Enterprise Risk Management relationships have a positive effect of 0.578 (Table 12) on the implementation of Good Corporate Governance. (Ho3 Accepted).

d. Testing the Relationship of Competitive Advantage to Good Corporate Governance if mediated through Enterprise Risk Management

the relationship of Competitive Advantage to Good Corporate Governance if mediated through Enterprise Risk Management has a positive effect of $(0.414 \times 0.578=0.239)$ on the implementation of Good Corporate Governance. It can be concluded that the competitive advantage will be greater with a direct relationship (0.365) compared to mediated through Enterprise Risk Management (0.239). In another sense, the role of enterprise risk management in mediating competitive advantage and good corporate governance relations has no significant effect. (Ho4 Denied).

\section{Conclusion}

From the results of tests conducted on all data taken from existing data samples, it can be concluded as follows.

1. Competitive Advantage directly has a positive effect of 0.365 on the implementation of Good Corporate Governance. (Ho1 Received)

2. Competitive Advantage directly has a positive effect of 0.414 on Enterprise Risk Management. (Ho2 Received)

3. Enterprise Risk Management relationship has a positive effect of 0.578 on the implementation of Good Corporate Governance. (Ho3 Accepted). These results are in accordance with the results of the study of Elena Demidenko and Patrick McNutt (2010) which concluded that the application of enterprise risk management has an effect and has become one of the keys in determining a better level of implementation of good corporate governance.

4. Relationship of Competitive Advantage to Good Corporate Governance if mediated through Enterprise Risk Management has a positive effect of $(0.414 \times 0.578=0.239)$ on the implementation of Good Corporate Governance. It can be concluded that the influence of competitive advantage on good corporate governance will be greater with a direct relationship (0.365) compared to mediated

through Enterprise Risk Management (0.239). In another sense, the role of enterprise risk management in mediating competitive advantage and good corporate governance relations has no significant effect. (Ho4 Denied). This might be due to differences in the competitive advantage each company has that affects the level of application of enterprise risk management in each company, supported by the results of Sara Soltanizadeh, Siti Zaleha, Abdul Rasid, Nargess Mottaghi Golshan, and Wan Khairuzzaman Wan Ismail (2016) Business enterprise strategy, risk management, and organizational performance find that companies with cost leadership business strategies are more motivated to implement ERM compared to companies with differentiation strategies. The results also show that ERM implementation has a significant positive impact on organizational performance. Although ERM is a partial mediator of the relationship between cost leadership strategies and organizational performance, ERM does not mediate the relationship between differentiation strategies and organizational performance.

The author is limited in collecting data samples in compiling this study. In this study, the role of enterprise risk management in mediating competitive advantage and good corporate governance relations was rejected. Hence, for further research, it is expected that further researchers can test this research model by adding other variables to the conditions or business environment and different cultures, to see the comparison of research results with different circumstances and cultures that might get different results.

\section{References}

Akram Jalal-Karim, (2013) "Leveraging enterprise risk management (ERM) for boosting competitive business advantages in Bahrain", World Journal of Entrepreneurship, Management and Sustainable Development, Vol. 9 Issue: 1, pp.65-75

Akram, J.-K. (2011), "The value of competitive business intelligence system (CBIS) to stimulate competitiveness in global market”, International Journal of Business and Social Science, Vol. 2 No. 19.

Anderson, K. and Terp, A. (2006), "Risk management”, in Andersen, T.J. (Ed.), Perspectives on Strategic Risk Management, Copenhagen Business School Press, Copenhagen, pp. 27-46. 
Arena,M.,Arnaboldi,M.andAzzone,G.(2010), "The organizational dynamics of enterprise risk management", Accounting, Organizations and Society, Vol. 35 No. 7, pp. 659-675.

Bailey, M.A., Bloom, L. and Hida, E.T. (2004), Assessing the Value of Enterprise Risk Management, Deloitte Development LLC.

Baroto, M.B., Abdullah, M.M. and Lai Wan, H. (2012), "Hybrid strategy: a new strategy for competitive advantage",International Journal of Business and Management, Vol.7No.20, pp.120-133.

Brooks, D.W. (2010), “Creating a risk-aware culture”, in Fraser, J.R.S. and Simkins, B.J. (Eds), Enterprise Risk Management: Today's Leading Research and Best Practices for Tomorrow’s Executives, John Wiley \& Sons, Inc, Hoboken, New Jersey.

Cescon,F.,Costantini,A.andRossi,G.(2013), The Influence of Business Strategy and Ownership on Management Accounting Innovations and Risk Management Techniques: An Empirical Analysis in Large Manufacturing Companies in Italy, University of Udine, Department of Economics and Statistics, Udine.

Cescon,F.,Costantini,A.andRossi,G.(2013),The Influence of Business Strategy and Ownership on Management Accounting Innovations and Risk Management Techniques: An Empirical Analysis in Large Manufacturing Companies in Italy, University of Udine, Department of Economics and Statistics, Udine

CIMA (2011), Enterprise risk management and budgetary control: a management challenge, Research executive summary series,, Vol. 7 Issue 6, Chartered Institute of Management Accountants

COSO. (2004). Enterprise risk management: integrated framework executive

CRMS Indonesia (2018), Survei Nasional Manajemen Risiko 2018, Center for Risk Management Studies, Indonesia

Daud,W.N.W.D.,Yazid,A.S.andHussin,H.M.R.(2010), “The effect of chief risk officer (CRO) on Enterprise Risk Management (ERM) practices: evidence from Malaysia”, International Business \& Economics Research Journal, Vol. 9 No. 11, pp. 55-64.

Daud,W.N.W.D.,Yazid,A.S.andHussin,H.M.R.(2010), “The effect of chief risk officer (CRO) on Enterprise Risk Management (ERM) practices: evidence from Malaysia”, International Business \& Economics Research Journal, Vol. 9 No. 11, pp. 55-64.

David L. Olson, Desheng Dash Wu, (2010) "A review of enterprise risk management in supply chain", Kybernetes, Vol. 39 Issue: 5, pp.694-706

Economist Intelligence Unit Limited and MMC Enterprise Risk Inc (2001), Enterprise Risk Management: Implementing New Solutions, Economist Intelligence Unit Limited and MMC Enterprise Risk Inc, New York, NY.

Elena Demidenko, Patrick McNutt, (2010) "The ethics of enterprise risk management as a key component of corporate governance", International Journal of Social Economics, Vol. 37 Issue: 10, pp.802-815

Frigo,M.andAnderson,R.J.(2012),Strategic Risk Mangement : The New Core Competency, John Wiley \& Sons, Hoboken, NJ.

Hoyt,R.E.andLiebenberg,A.P.(2011), “The value of enterprise risk management”, Journal of Risk and Insurance, Vol. 78 No. 4, pp. 795-822.

Kristaung, Robert and Yvonne Augustine (2018) "Metodologi Penelitian Bisnis dan Akuntansi, Edition. 2. Dian Rakyat, Jakarta.

Lai, F.W. and Samad, F.A. (2010), "Enterprise risk management framework and the empirical determinants of its implementation”, 2010 International Conference on Business and Economics, available at : www.ipedr.com/vol1/73-G10003.pdf (accessed30January2014).

Lappalainen, J. and Niskanen, M. (2012), "Financial performance of SMEs: impact of ownership structure and board composition”, Management Research Review, Vol. 35 No. 11, pp.1088-1108.

Lappalainen, J. and Niskanen, M. (2012), "Financial performance of SMEs: impact of ownership structure and board composition”, Management Research Review, Vol. 35 No. 11, pp.1088-1108

Miccolis, J. and Shah, S. (2000), Enterprise Risk Management: An Analytic Approach, Tillinghast-Towers Perrin,Parsippany,NJ.

Nadine Gatzert, Joan Schmit, (2016) "Supporting strategic success through enterprise-wide reputation risk management", The Journal of Risk Finance, Vol. 17 Issue: 1, pp.26-45

Razali,A.R.,Yazid,A.S.andTahir,I.M.(2011), "The determinants of enterprise risk management (ERM) practices in Malaysian public listed companies", Journal of Social and Development Sciences,Vol.1No.5,pp.202-207.

Sara Soltanizadeh, Siti Zaleha Abdul Rasid, Nargess Mottaghi Golshan, and Wan Khairuzzaman Wan Ismail (2016) “Business strategy, enterprise risk management and organizational performance" Management Research Review, Vol. 39 Issue: 9, pp.1016-1033 